\title{
High selfing capability and low pollinator visitation in the hummingbird-pollinated epiphyte Pitcairnia heterophylla (Bromeliaceae) at a Costa Rican mountain forest
}

\author{
Luis D. Ríos* \& Alfredo Cascante-Marín \\ Escuela de Biología, Universidad de Costa Rica, 11501-2060 San Pedro de Montes de Oca, San José, Costa Rica; \\ 1drios18@gmail.com, alfredo.cascante@ucr.ac.cr \\ * Correspondence
}

Received 16-VIII-2016. Corrected 20-I-2017. Accepted 07-II-2017.

\begin{abstract}
Pitcairnioideae is the second most diverse subfamily of bromeliads (Bromeliaceae), a group exclusive to tropical regions of the New World. Pitcairnioid bromeliads have floral traits assumed to promote outcrossing through biotic pollination systems; however, the reproductive biology of most of the species of this group has not been documented. Pitcairnia heterophylla is an epiphytic (seldom saxicolous) bromeliad occurring from Southern Mexico, into the Northern Andes. We studied the pollination and breeding system of $P$. heterophylla in an epiphytic population at a mountain forest in Costa Rica from January to April 2013. We performed hand pollination experiments (agamospermy, autonomous self-pollination, hand self-pollination and hand cross-pollination) on 89 flowers from 23 individuals (3-6 flowers per individual) in 2013 flowering season. Nectar production was measured on 18 unvisited flowers of six individuals with a hand-held refractometer. Simultaneously, floral visitors were recorded on eight individuals with trail cameras for a total of 918 hours (115 \pm 52 hours per individual, mean $\pm \mathrm{SE}$ ). Under natural conditions, seed set $(540.4 \pm 55.2)$ was similar to manually selfed flowers $(516.3 \pm 41.5)$ and autonomously selfed flowers $(521.1 \pm 29.0)$, but lower to manually outcrossed flowers $(670.2 \pm 31.3)$. The flowers of $P$. heterophylla are self-compatible, capable of autonomous pollination, and non-agamospermous. Intrafloral self-pollination is facilitated by adichogamy and lack of floral herkogamy. The scentless red flowers of $P$. heterophylla with tubular corollas and nectar production suggested ornithophilic pollination which was confirmed by video recording of 46 hummingbird visits. The most common floral visitor was the short-billed hummingbird Lampornis calolaemus which accounted for $78 \%$ of the visits. However, the visitation rate during the flowering season was low ( 0.6 visits per day per plant). Selfing in P. heterophylla might be explained as a mechanism of reproductive assurance and to reduce interspecific pollen flow with taxonomically unrelated plants. Rev. Biol. Trop. 65 (2): 735-743. Epub 2017 June 01.
\end{abstract}

Key words: breeding system, hummingbird pollination, specialized pollination, reproductive assurance, selfing, autogamy, Pitcairnioideae.

The Bromeliaceae family is a highly diverse group of monocotyledonous plants exclusive to the Neotropics (Benzing, 2000) and, nearly $56 \%$ (1770 spp.) of their members inhabits the forest canopy as epiphytes (Zotz, 2013). Bromeliads display specialized pollination systems which involve particular floral traits and pollen vectors, from bees to hummingbirds and bats, in a relationship intended to promote pollen exchange and an outcrossing mating system (Ackerman, 1986; Benzing, 2000).

The breeding systems of bromeliads have been scarcely documented, particularly for epiphytic species. However, the few studies done so far (which represent only $2.5 \%$ of the species) suggest a high incidence of selfcompatibility and autonomous self-pollination (reviewed by Matallana et al., 2010). Molecular studies of the mating system of some epiphytic 
bromeliads have reported high selfing and corroborated their ability for self-pollination and self-compatibility (Cascante-Marín et al., 2006).

Bromeliads of sub-family Pitcairnioideae (sensu stricto; Givnish, Millam, Berry, \& Sytsma, 2007) constitute the second most diverse group within the family (Smith \& Downs, 1974) and has received less attention in studies of reproductive biology compared to subfamilies Tillandsioideae and Bromelioideae (Ramírez-Morillo, Chi-May, Carnevali \& May-Pat, 2009; Matallana et al., 2010). The most diverse group within Pitcairnioideae is the genus Pitcairnia with ca. 260 species (Smith \& Downs, 1974). Pitcairnia is a monophyletic group native to the Amazon basin, Northern Andes, Guayana Shield, Central America, and the Caribbean (Givnish et al., 2007). Most Pitcairnia species possess tubular and showy flowers, usually red or less frequently white or yellow (Smith \& Downs, 1974) that are visited by hummingbirds (Fumero-Cabán \& Meléndez-Ackerman, 2007; Bush \& Guilbeau, 2009). Thus far, self-compatibility and selfpollination has been documented in six Pitcairnia species (Wendt, Canela, de Faria, \& Rios, 2001; Wendt, Canela, Klein, \& Rios, 2002; Fumero-Cabán \& Meléndez-Ackerman, 2007; Bush \& Guilbeau, 2009).

Matallana et al. (2010), suggested that self-pollination and self-compatibility in bromeliads evolved as a mechanism to avoid interspecific pollen flow among congeners in highly diverse ecosystems. Alternatively, the ability to self-pollinate might also serve to counteract pollinator unpredictability and facilitate reproductive assurance when pollinator visits are limited (Levin, 1972). The presence of reproductive traits that facilitate self-pollination among plants with bisexual flowers and specialized pollination systems may function as a mechanism of reproductive assurance (Fenster \& Martén-Rodríguez, 2007) and facilitate the maintenance of a mixed mating system (Goodwillie, Kalisz, \& Eckert, 2005). Such a mechanism operates in way that enables plants to produce offspring whenever pollinator visitation is infrequent or there are few potential mates available (Eckert, Samis, \& Dart, 2006). Understanding the evolution and maintenance of breeding systems in Pitcairnia requires further information on their reproductive biology and pollination systems, which at present are scarcely documented. This information is also essential to explain processes such as gene flow and genetic structuring in epiphytic plant populations (e.g., Cascante-Marín, Oostermeijer, Wolf, \& Fuchs, 2014).

In this paper, we studied the pollination and mating system of Pitcairnia heterophylla (Lindl.) Beer, an epiphytic (seldom saxicolous) and $\mathrm{C}_{3}$-type bromeliad (Reinert, Russo, \& Salles, 2003). The day-blooming flowers of $P$. heterophylla have a tubular and red corolla, lack scent and produce nectar; floral traits that suggests bird pollination (Willmer, 2011). We examined the reproductive biology of a population of $P$. heterophylla in a Costa Rican mountain forest. Our research had the following objectives: 1) to describe the floral biology and nectar production, 2) to determine the plant's breeding system using manual pollination treatments, and 3) to estimate pollinator visitation rates.

\section{MATERIALS AND METHODS}

Study site: Field work was conducted in a mountain cloud forest in the vicinity of the Central Valley in Costa Rica, Cartago province (0953'20" N - 8358'10" W), known as La Carpintera. The site consists of an elevated mountainous terrain with an altitudinal gradient from 1500 to $1800 \mathrm{~m}$ in elevation. Mean annual precipitation is $1839.2 \mathrm{~mm}$ and mean annual temperature is $16.1^{\circ} \mathrm{C}$. The annual distribution of rainfall follows a seasonal pattern, with a period of low precipitation or dry season ( $<60 \mathrm{~mm}$ per month) from December to April (IMN, undated). The forested area consists of an irregular fragment of nearly 2400 ha that covers the ridge and mountain slopes and is mostly composed of old secondary forest ( $>$ 50 years) interspersed with older remnant forest patches. Some representative forest trees 
are Quercus spp., Ficus spp., and members of Lauraceae, among others (Sánchez, Durán, \& Vega, 2008).

Study species: Pitcairnia heterophylla has a wide geographic distribution from Mexico to Venezuela and Peru, between 100-2 $500 \mathrm{~m}$ in elevation (Smith \& Downs, 1974). Ramets possess dimorphic leaves: spiny-serrate modified leaves and long linear leaves that are shed previous to floral anthesis (Fig. 1 A, Fig. 1B). Individual plants (i.e. genets) of $P$. heterophylla at the studied population were composed of three to 73 ramets (mean $=31.4 \pm 21.7 \mathrm{SD}, \mathrm{N}$ $=20$ ). Each ramet develops a single and short (ca. $2.5 \mathrm{~cm}$ ) terminal inflorescence with 5-17 hermaphroditic flowers (mean length $=4.0 \pm$ $0.2 \mathrm{~cm}, \mathrm{~N}=20$ ) (Fig. 1C). Fruits are dehiscent dry capsules that release wind-dispersed seeds (Smith \& Downs, 1974). The studied population exhibits an annual flowering pattern from January to March (dry season) and seed dispersal takes place in the following dry season (Cascante-Marín, unpubl. data). A voucher specimen was deposited at the herbarium of the University of Costa Rica (Ríos 28, USJ).

Breeding system: From January to April 2013, we performed controlled pollination experiments on 89 flowers from 23 individuals
(3-6 flowers per individual). Flowers within a plant were assigned to the following treatments: (1) agamospermy (flowers had their stigma removed at the beginning of anthesis); (2) autonomous self-pollination (un-manipulated bagged flowers); (3) hand self-pollination (flowers hand-pollinated with their own pollen); (4) hand cross-pollination (previously emasculated flowers hand-pollinated with pollen from another plant), and (5) natural pollination (unmanipulated and randomly selected flowers exposed to pollinators in the field). Pollen was removed from the anthers and applied on the stigma using a thin brush. Manipulations were carried out with plants kept in a greenhouse at the study site. Fruit and seed set were evaluated ten months after pollination treatments.

The breeding system was determined using Lloyd and Schoen's (1992) self-compatibility index $\left(\mathrm{SCI}_{\mathrm{f}}\right)$, autofertility index $\left(\mathrm{AFI}_{\mathrm{f}}\right)$ and, Ramírez and Brito's (1990) index of agamospermy $\left(\mathrm{AG}_{\mathrm{f}}\right)$. $\mathrm{SCI}_{\mathrm{f}}$ was calculated by dividing the mean number of seeds per fruit in the selfpollination treatment by the number of seeds in the artificial cross-pollination treatment. $\mathrm{AFI}_{\mathrm{f}}$ was estimated by dividing the mean seed number per fruit in the autonomous self-pollination treatment by the seeds produced by the handcrossed pollination experiment. Finally, $\mathrm{AG}_{\mathrm{f}}$ was calculated as the ratio of seeds produced
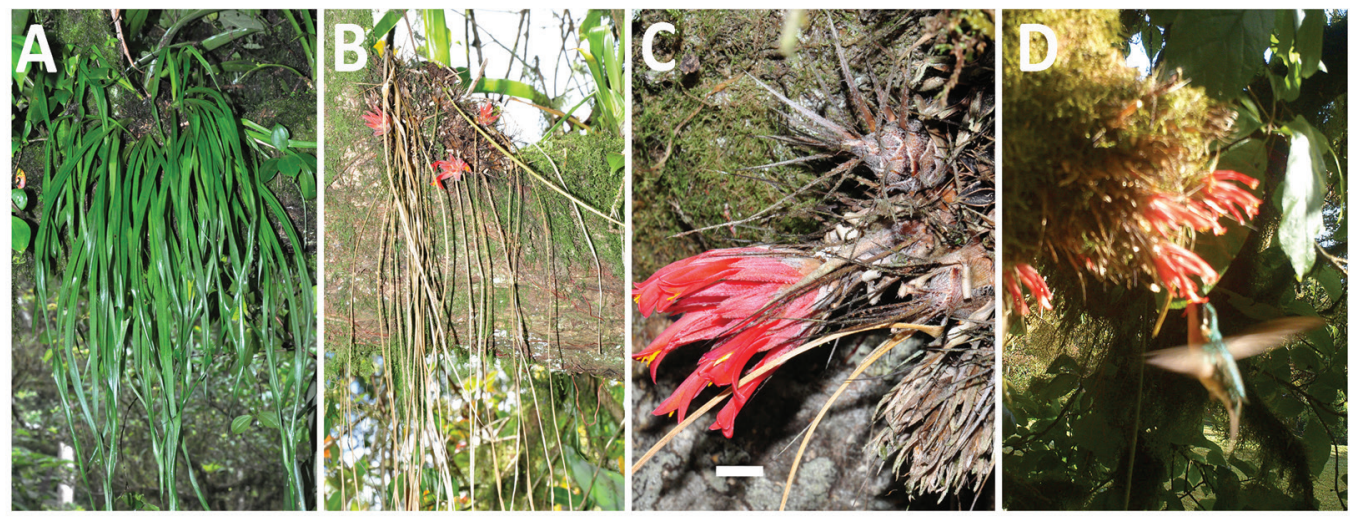

Fig. 1. (A) An epiphytic genet of Pitcairnia heterophylla (Bromeliaceae, Pitcairnioideae) with the long linear leaves. (B) A leafless genet during the flowering period, note the showy red inflorescences and the presence of dried leaves still attached to the ramets. (C) Close-up of an inflorescence, note the short peduncle and the ramets formed by modified spinose leaves; scale bar $=1 \mathrm{~cm}$. (D) A female hummingbird, Lampornis calolaemus (Trochilidae), visiting the flowers of P. heterophylla. 
in the agamospermy treatment to the seeds developed in naturally pollinated flowers. Differences in seed production among treatments were statistically compared by means of a Generalized linear mixed model (GLMM), using a Poisson distribution and a log link function, with pollination treatment as a fixed factor and flowers nested within individuals as a random factor. Further pair-wise comparisons between treatments were performed with Tukey's HSD Test. Analyses were performed in R (R Development Core Team, 2015), using the lme4 (Bates, Maechler, Bolker, \& Walker, 2015) and Multcomp packages (Hothorn, Bretz, \& Westfall, 2008).

Flower development and nectar production: Inflorescence and flower development were recorded on 20 randomly chosen individuals in the field in the 2013 flowering season. For each individual, we recorded inflorescence development and floral anthesis. Individual flower development was recorded in one flower per inflorescence. Nectar volume and sugar concentration were analyzed in 18 unvisited flowers of six individuals at $3 \mathrm{hr}$ intervals from 06:00 to 18:00 hr. Flowers were protected with a mesh bag and nectar was measured by inserting a calibrated micropipette. Nectar concentration ( $\%$ sucrose) was estimated with a hand-held refractometer (Bellingham \& Standley Ltd., United Kingdom) at 22-24 ${ }^{\circ} \mathrm{C}$.

Flower visitors: The identity and visitation frequency of potential pollinators under natural conditions was documented with trail cameras (Trophy Cam, Bushnell Corp., Overland Park,
Kansas, USA). We filmed inflorescences from eight genets from January 29 to February 27, 2013; cameras were positioned about one meter away to facilitate visitor's identification. We recorded visits from 06:00 to 18:00 hr and for an average filming time of $115( \pm 52)$ hours per plant, totaling 918 recording hours. We considered a legitimate visit whenever a visitor contacted both pistil and stamens. The visitation rate was calculated as the mean number of visits per hour across monitored genets.

\section{RESULTS}

Breeding system: Fruit set was lower (89 \%) under autonomous pollination compared with artificially (selfed and crossed) and naturally pollinated flowers (Table 1). Seed set significantly differed among pollination treatments $(F=97.01$, d.f. $=4, \mathrm{P}<0.01)$. Manually cross-pollinated flowers produced the highest number of seeds, followed by flowers exposed to natural pollination and manually self-pollinated flowers; however, the differences were not statistically significant among them (Table 1). The relatively high value of $\mathrm{SCI}_{\mathrm{f}}$ and $\mathrm{AFI}_{\mathrm{f}}$ (0.77 and 0.78, respectively) indicates that $P$. heterophylla is self-compatible and capable of autonomous pollination. Agamospermy was a negligible mechanism in this epiphyte, $\mathrm{AG}_{\mathrm{f}}=0.01$.

Floral biology and nectar production: Inflorescence bud development initiated in early November. Inflorescences completed their development within three to four weeks and by mid-January the population flowering

TABLE 1

Results from natural and hand-pollination treatments in Pitcairnia heterophylla at a montane forest in Costa Rica. Letters represent significant differences between treatments after a Tukey's HSD test

\begin{tabular}{lcccc}
\multicolumn{1}{c}{ Treatment } & No. of genets & No. of flowers & Fruit set (\%) & Seed set (mean \pm SE) \\
Hand cross-pollination & 6 & 19 & 100 & $670.2 \pm 31.3^{\mathrm{a}}$ \\
Hand self-pollination & 9 & 15 & 100 & $516.3 \pm 41.5^{\mathrm{a}}$ \\
Open pollination (control) & 8 & 20 & 100 & $540.4 \pm 55.2^{\mathrm{a}}$ \\
Autonomous self-pollination & 6 & 29 & 89 & $521.1 \pm 29.0^{\mathrm{a}}$ \\
Agamospermy & 7 & 15 & 6.7 & $5.1 \pm 5.1^{\mathrm{b}}$ \\
\hline
\end{tabular}


season had started. A single inflorescence opened flowers from one to three weeks. No evidence of dichogamy or herkogamy was detected. Mean accumulated volume of nectar in unvisited flowers was $6.9 \mu \mathrm{L} \pm 0.9( \pm \mathrm{SE})$ (Fig. 2A), with a mean sucrose concentration of $16.6 \pm 0.6 \%$ (Fig. 2B). Major nectar secretion and sucrose concentration occurred during early anthesis in the morning at around 6:00 hr (Fig. 2A, Fig. 2B).

Pollinators and floral visitation: Shortbilled hummingbirds (Trochilinae) were the main visitors to $P$. heterophylla flowers. Lampornis calolaemus (Salvin, 1865; Fig. 1D) accounted for most (78 \%) of the recorded visits, followed by Eupherusa eximia (DeLattre, 1843), and Selasphorus scintilla (Gould, 1851). Peak activity in the visitation pattern occurred between 10:00 and 13:00 hr, comprising $61 \%$
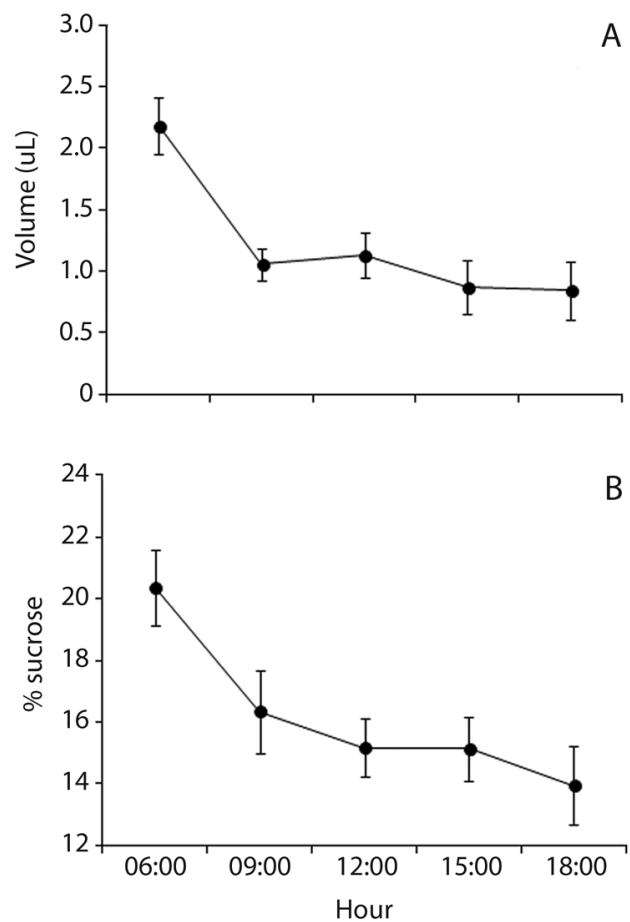

Fig. 2. Diurnal pattern of nectar production of unvisited flowers of Pitcairnia heterophylla (Bromeliaceae, Pitcairnioideae) at a montane forest in Costa Rica. Data are mean values from measurements on 18 flowers at 3 hours' intervals (vertical bars $=1 \mathrm{SE}$ ). of the recorded visits (Fig. 3). Only 46 visits to 97 flowers were recorded over 918 hours of video monitoring and the daily and hourly visitation rate per inflorescence was rather low (0.6 visits per day, mean $=0.05$ visits per hour; range $=0.0-0.19)$. A nectar robber (Diglossa plumbea [Cabanis, 1861], Passeriformes: Emberizidae) and a floral herbivore, the red-tailed squirrel (Sciurus granatensis [Humboldt, 1811], Rodentia: Sciuridae), were also recorded visiting inflorescences of the study species.

\section{DISCUSSION}

Our results corroborated that $P$. heterophylla is hummingbird pollinated; as previously inferred from its floral morphology, which comprises scentless flowers with vivid scarlet, tubular corollas, and nectar production (Willmer, 2011). Pollination by hummingbirds could be a widespread tendency among Pitcairnia, in both epiphytic (Bush \& Guilbeau, 2009) and terrestrial species (Wendt et al., 2001; 2002), as suggested by the group's floral morphology (Smith \& Downs, 1974).

Leaf shedding coupled with flower anthesis in P. heterophylla is likely to increase flower

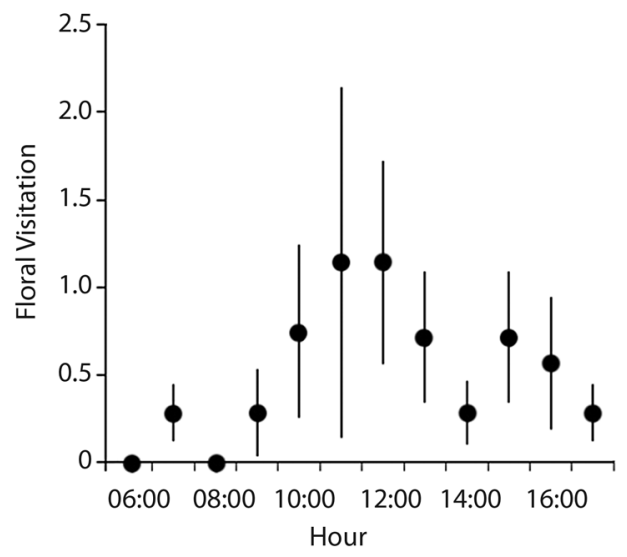

Fig. 3. Rate of hummingbird visitation to inflorescences of Pitcairnia heterophylla (Bromeliaceae, Pitcairnioideae) at a montane forest in Costa Rica. Data are average numbers of visits per hour (lines are $\pm 1 \mathrm{SE}$ ) from the reproductive 2013 season and comprising 918 observation hours on eight individuals. Total visits $=46$. 
visibility and pollinator attraction (Fig. 1A, Fig. 1B). In most other Pitcairnia species the longer $(>20 \mathrm{~cm})$ inflorescences lie above the leaves (Smith \& Downs, 1974), while the short (ca. $2.5 \mathrm{~cm}$ ) inflorescence of $P$. heterophylla could potentially be concealed by the long linear photosynthetic leaves. However, at the time of flowering, ramets of $P$. heterophylla have shed the linear leaves and inflorescences are exposed and accessible to pollinators. Hummingbirds visually search for their food source; thus flowers must be exposed in order to attract them (Faegri \& van der Pijl, 1979; Feinsinger, Tiebout, \& Young 1991). Leaf shedding in some tropical dry forest trees is hypothesized to increase flower visibility and pollinator visitation (Janzen, 1967). Several Pitcairnia species have deciduous leaves (Smith \& Downs, 1974); however, whether this represents an adaptation to increase pollinator visitation requires experimental evaluation.

Although the inflorescence of $P$. heterophylla are conspicuous and exposed, visitation rate ( 0.6 visits per day) was rather low when compared to other hummingbird pollinated plants (Feinsinger, 1978; Bush \& Guilbeau, 2009). The reward offered by $P$. heterophylla to pollinators may discourage their visitation since nectar production and sugar concentration was lower than estimates reported for other hummingbird pollinated species (Krömer, Kessler, Lohaus \& Schmidt-Lebuhn, 2008; Fumero-Cabán \& Meléndez-Ackerman, 2012). The local abundance of pollinators and competitive interactions among hummingbird-pollinated plants in the community may have also influenced our observations (Stiles, 1975); however, we did not evaluate these factors. At the study site, the flowering phenology of $P$. heterophylla overlaps with the flowering of at least 11 more hummingbird-pollinated species (Cascante-Marín, unpubl. data).

Our results from the breeding system analysis suggest the potential to sire progeny by autonomous means. Selfing in P. heterophylla is facilitated by self-compatibility $\left(\mathrm{SCI}_{\mathrm{f}}=\right.$ 0.77 ), adichogamy or simultaneous maturation of reproductive organs, and the absence of herkogamy. The pollination system of $P$. heterophylla promotes high outcrossing rates but its ability to self-pollinate suggests a mixed mating system. Mixed mating is a common reproductive phenomenon among plants pollinated by biotic vectors (Goodwillie et al., 2005) and has been reported in other Pitcairnia species (Wendt et al., 2001, 2002; FumeroCabán \& Meléndez-Ackerman, 2007; Bush \& Guilbeau, 2009). Self-compatibility and autonomous selfing is a common reproductive strategy among epiphytic bromeliads (Matallana et al., 2010); however, the studies that evaluate the role of selfing and outcrossing on mating systems of bromeliads by means of molecular analysis of the progeny are scare (CascanteMarín et al., 2006).

The ability of $P$. heterophylla to selfpollinate might represent a mechanism to cope with unpredictable pollination and ensure the production of seeds. The presence of floral mechanisms that facilitate autonomous selfing are common among plants with specialized pollination systems (Fenster \& Martén-Rodríguez, 2007). In general, the evolution of selfing in plants has been interpreted as a means to attain reproductive assurance whenever visits by pollinators are scare, or there are few potential mates in the population (Jain, 1976; Holsinger, 2000; Charlesworth, 2006). In epiphytic plants, autogamy has been interpreted as a mechanism to compensate for their apparent reduced capacity to attract pollinators due to their low floral display and highly aggregated spatial distribution in the forest canopy (Bush \& Beach, 1995).

Selfing, on the other hand, may increase inbreeding in $P$. heterophylla because of the apparent lower seed production from manually selfed flowers compared to cross-pollination which suggests a reduction in female fitness through seed discounting (Lloyd, 1992). Nonetheless, the role of selfing as a mechanism for reproductive assurance in $P$. heterophylla, requires measuring its contribution to seed set and the potential effects of inbreeding on plant fitness by measuring seed germination and plant growth over several reproductive 
events (Eckert et al., 2006). Additionally, $P$. heterophylla is the only representative of the genus in the studied site, thus selfing is not likely a mechanism to reduce interspecific pollen flow among sympatric species as proposed by Matallana et al. (2010). However, interspecific pollen flow may occur from taxonomically unrelated species visited by the same pollinator. Both hypotheses on the maintenance of selfing on the studied species might not be mutually exclusive and could be operating simultaneously.

\section{ACKNOWLEDGMENTS}

The Guides and Scouts Association of Costa Rica granted permission to conduct the research at the Iztarú Camp at Cerros La Carpintera. Gilbert Barrantes and Diego Ocampo (UCR) identified the hummingbirds. Two anonymous reviewers provided valuable comments that improved the quality of the manuscript. This work was supported by Vicerrectoría de Investigación at Universidad de Costa Rica (project 111-B2-041 awarded to ACM). The Agencia Española de Cooperación Internacional y de Desarrollo (AECI) provided funds to acquire video camera equipment (funds $\mathrm{D} / 027406 / 09$ and $\mathrm{D} / 033858$ to Universidad de Las Palmas de Gran Canaria and Universidad de Costa Rica).

\section{RESUMEN}

Alta capacidad de autofecundación y baja visitación de polinizadores en la epífita polinizada por colibríes Pitcairnia heterophylla (Bromeliaceae) en un bosque montano en Costa Rica. La subfamilia Pitcairnioideae es la segunda más diversa de las bromelias (Bromeliaceae), un grupo exclusivo de la región Neotropical. Las bromelias pitcairnioideas poseen rasgos florales que se asume promueven el exo-cruzamiento a través de sistemas de polinización biótica; sin embargo, la biología reproductiva de la mayoría de especies de este grupo no se ha documentado. Pitcairnia heterophylla es una bromelia epífita (raramente saxícola) que se encuentra en el sur de México, América Central y el norte de los Andes. Se estudió la polinización y el sistema de apareamiento de una población $P$. heterophylla en un bosque montano en Costa Rica entre enero y abril 2013. Se realizaron cuatro experimentos de polinización (agamospermia, auto-polinización espontánea, auto-polinización manual, exo-polinización manual) en 89 flores de 23 individuos (3-6 flores por individuo). Se cuantificó la producción de néctar de 18 flores en seis individuos con un refractómetro. Simultáneamente, se registraron los visitantes florales de ocho individuos en el campo con ayuda de cámaras trampa por un total de 918 horas $(115 \pm 52$ horas por individuo, promedio \pm ES). Bajo condiciones naturales la producción de semillas fue similar $(540.4 \pm 55.2)$ a la producción de las flores auto-polinizadas manualmente $(516.3 \pm 41.5)$ y las flores auto-polinizadas espontáneamente $(521.1 \pm 29.0)$, pero fue menor a las flores exo-cruzadas $(670.2 \pm 31.3)$. Las flores de $P$. heterophylla son auto-compatibles, con alta capacidad de polinización espontánea y sin capacidad de agamospermia. La auto-polinización intra-floral es facilitada por la ausencia de dicogamia y hercogamia floral. Las flores rojas, sin aroma, con corola tubular y con producción de néctar sugirieron polinización por ornitofilia, lo que se confirmó con el registro de 46 visitas por colibríes (Apodiformes: Trochilidae). El visitante floral más común fue Lampornis calolaemus (78\% de las visitas). A pesar de esto, la tasa de visitas durante el periodo de estudio fue baja (0.6 visitas por día por planta). La capacidad de autofecundación de $P$. heterophylla puede ser explicada como un mecanismo de aseguramiento reproductivo, así como para reducir el flujo de polen inter-específico de plantas taxonómicamente no relacionadas.

Palabras clave: sistema de apareamiento, polinización por colibríes, polinización especializada, aseguramiento reproductivo, autofecundación, autogamia, Pitcairnioideae.

\section{REFERENCES}

Ackerman, J. D. (1986). Coping with the epiphytic existence: pollination strategies. Selbyana, $9(1), 52-60$.

Bates, D., Maechler, M., Bolker, B., \& Walker, S. (2015). Fitting linear mixed-effects models using lme4. Journal of Statistical Software, 67(1), 1-48. http://doi. org/10.18637/jss.v067.i01

Benzing, D. H. (2000). Bromeliaceae: profile of an adaptive radiation (1st ed). Cambridge: Cambridge University Press.

Bush, S. P., \& Beach, J. H. (1995). Breeding systems of epiphytes in a tropical montane wet forest. Selbyana, 16(2), 155-158.

Bush, S. P., \& Guilbeau, J. E. (2009). Early autonomous selfing in the hummingbird-pollinated epiphyte Pitcairnia brittoniana (Bromeliaceae). Journal of the Torrey Botanical Society, 136(3), 313-321.

Cascante-Marín, A., Jong, M. De, Borg, E. D., Oostermeijer, J. G. B., Wolf, J. H. D., \& den Nijs, J. C. M. (2006). Reproductive strategies and colonizing 
ability of two sympatric epiphytic bromeliads in a tropical premontane area. International Journal of Plant Sciences, 167(6), 1187-1195. doi: http://doi. org/10.1086/507871

Cascante-Marín, A., Oostermeijer, G., Wolf, J., \& Fuchs, E. J. (2014). Genetic diversity and spatial genetic structure of an epiphytic bromeliad in Costa Rican montane secondary forest patches. Biotropica, 46(4), 425-432. doi: http://doi.org/10.1111/btp.12119

Charlesworth, D. (2006). Evolution of plant breeding systems. Current Biology, 16(17), R726-735. doi: http:// doi.org/10.1016/j.cub.2006.07.068

Eckert, C. G., Samis, K., \& Dart, S. (2006). Reproductive assurance and the evolution of uniparental reproduction in flowering plants. In L. Harder \& S. C. H. Barrett (Eds.), Ecology and Evolution of Flowers (pp. 181-203). New York: Oxford University Press.

Faegri, K., \& van der Pijl, L. (1979). The Principles of Pollinaton Ecology (3rd ed.). London, UK: Pergamon Press.

Feinsinger, P. (1978). Ecological interactions between plants and hummingbirds in a successional tropical community. Ecological Monographs, 48(3), 269-287. doi: http://doi.org/10.2307/2937231

Feinsinger, P., Tiebout, H.M. III, \& Young, B. E. (1991). Do tropical bird-pollinated plants exhibit density-dependent interactions? field experiments. Ecology, 72(6), 1953-1963. doi: http://doi.org/10.2307/1941550

Fenster, C. B., \& Martén-Rodríguez, S. (2007). Reproductive assurance and the evolution of pollination specialization. International Journal of Plant Sciences, 168(2), 215-228. doi: http://doi.org/10.1086/509647

Fumero-Cabán, J. J., \& Meléndez-Ackerman, E. J. (2007). Relative pollination effectiveness of floral visitors of Pitcairnia angustifolia (Bromeliaceae). American Journal of Botany, 94(3), 419-424. doi: http://doi. org/10.3732/ajb.94.3.419

Fumero-Cabán, J. J., \& Meléndez-Ackerman, E. J. (2012). Effects of nectar robbing on pollinator behavior and plant reproductive success of Pitcairnia angustifolia (Bromeliaceae). Plant Species Biology, 28(3), 224-234. doi: http://doi. org/10.1111/j.1442-1984.2012.00388.x

Givnish, T. J., Millam, K. C., Berry, P. E., \& Sytsma, K. J. (2007). Phylogeny, adaptive radiation, and historical biogeography of Bromeliaceae inferred from ndhF sequence data. Aliso, 23, 3-26. doi: http://doi. org/10.5642/aliso.20072301.04

Goodwillie, C., Kalisz, S., \& Eckert, C. G. (2005). The evolutionary enigma of mixed mating systems in plans: occurrence, theoretical explanations, and empirical evidence. Annual Review of Ecology, Evolution, and
Systematics, 36(1), 47-79. doi: http://doi.org/10.1146/ annurev.ecolsys.36.091704.175539

Holsinger, K. E. (2000). Reproductive systems and evolution in vascular plants. Proceedings of the National Academy of Sciences of the United States of America, 97(13), 7037-7042. doi: http://doi.org/10.1073/ pnas.97.13.7037

Hothorn, T., Bretz, F., \& Westfall, P. (2008). Simultaneous inference in general parametric models. Biometrical Journal, 50(3), 346-363.

Jain, S. K. (1976). The evolution of inbreeding in plants. Annual Review of Ecology and Systematics, 7, 469-495. doi: http://doi.org/10.1146/annurev. es.07.110176.002345

Janzen, D. H. (1967). Synchronization of sexual reproduction of trees within the dry season in Central America. Evolution, 21(3), 620-637. doi: http://doi. org/10.2307/2406621

Krömer, T., Kessler, M., Lohaus, G., \& Schmidt-Lebuhn, A. N. (2008). Nectar sugar composition and concentration in relation to pollination syndromes in Bromeliaceae. Plant Biology, 10(4), 502-11. doi: http://doi. org/10.1111/j.1438-8677.2008.00058.x

Levin, D. A. (1972). Competition for pollinator service: a stimulus for the evolution of autogamy. Evolution, 26(4), 668-669.

Lloyd, D. G. (1992). Self- and cross-fertilization in plants. II. The selection of self-fertilization. International Journal of Plant Biology, 153(3), 370-380.

Lloyd, D. G., \& Schoen, D. J. (1992). Self- and Cross- fertilization in Plants. I. Functional dimensions. International Journal of Plant Sciences, 153(3), 358-369.

Matallana, G., Godinho, M. A. S., Guilherme, F. A. G., Belisario, M., Coser, T. S., \& Wendt, T. (2010). Breeding systems of Bromeliaceae species: evolution of selfing in the context of sympatric occurrence. Plant Systematics and Evolution, 289(1), 57-65. doi: http:// doi.org/10.1007/s00606-010-0332-z

R Development Core Team (2015). R: A language and environment for statistical computing. Vienna: $\mathrm{R}$ Foundation for Statistical Computing.

Ramírez, N., \& Brito, Y. (1990). Reproductive biology of a tropical palm swamp community in the Venezuelan Llanos. American Journal of Botany, 77(10), 1260-1271.

Ramírez-Morillo, I. M., Chi-May, F., Carnevali, G., \& May-Pat, F. (2009). It takes two to tango: self incompatibility in the bromeliad Tillandsia streptophylla (Bromeliaceae) in Mexico. Revista de Biología Tropical, 57(3), 761-770. 
Reinert, F., Russo, C. A. M., \& Salles, L. O. (2003) The evolution of CAM in the subfamily Pitcairnioideae (Bromeliaceae). Biological Journal of the Linnean Society, 80(2), 261-268. doi: http://doi. org/10.1046/j.1095-8312.2003.00238.x

Sánchez, J., Durán, F., \& Vega, G. (2008). Diversidad de plantas, mamíferos y mariposas en los Cerros de la Carpintera, Costa Rica. San José: Museo Nacional de Costa Rica.

Smith, L. B., \& Downs, R. J. (1974). Pitcairnioideae (Bromeliaceae). Flora Neotropica, 14(1), 1-609. http:// doi.org/

Stiles, F. G. (1975). Ecology, flowering phenology, and hummingbird pollination of some Costa Rican Heliconia species. Ecology, 56(2), 285-301. http://doi. org/10.2307/1934961
Wendt, T., Canela, M. B., Gelli de Faria, A. P., \& Rios, R. I. (2001). Reproductive biology and natural hybridization between two endemic species of Pitcairnia (Bromeliaceae). American Journal of Botany, 88(10), 1760-1767.

Wendt, T., Canela, M. B. F., Klein, D. E., \& Rios, R. I. (2002). Selfing facilitates reproductive isolation among three sympatric species of Pitcairnia (Bromeliaceae). Plant Systematics and Evolution, 232, 201-212. doi: http://doi.org/10.1007/s006060200043

Willmer, P. (2011). Pollination and Floral Ecology. New Jersey: Princeton University Press.

Zotz, G. (2013). The systematic distribution of vascular epiphytes - a critical update. Botanical Journal of the Linnean Society, 171(3), 453-481. doi: http://doi. org/10.1111/boj.12010 
